national science policy, though all too

\title{
What price excellence?
}

Glasgow

For the second year running, the blueand-white insignia of the British Association of Science match the pyjamas of its president. Such complementary colouring, as Sir George Porter, the new president, assured his predecessor last Friday, is intended to encourage dedication to the job. Given the depressed state of basic science in Britain, as described during the British Association (BA) audit on science spending, Sir George should have many opportunities to coordinate his silver pendant with his nightwear.

Sir Hans Kornberg's opening address to the BA's annual meeting as outgoing president set a sombre tone at the University of Strathclyde (Glasgow) last week. One index, he says, of the "horrifying rate of decline" of British research is the inability of the Science and Engineering Research Council (SERC) to fund three-fourths of its finest research grant applications. $\mathrm{He}$ was the first of many to defend the role of basic research in improving Britain's industrial and scientific health. Science must be put to use (the primary theme of the meeting), in other words, but at what cost? By making "purely academic research by people motivated solely by the desire to know" the scapegoat for the failure to profit from this research, Britain would moulder as an "exploiter of imported ideas" and an "assembler of imported parts".

A week of rain and mud up to the knees on visits to scientific sites created a proper Shakespearean backdrop to these discussions. The host university, however, is used to such weather and showed many signs of spirit. Mr Hugh Thomson, head of Strathclyde's Research and Development Services, expressed high hopes for the fledgling science park, as well as pointing to the $£ 1.5$ million in research contracts recently won from the European Economic Community, an amount far above average for British universities. And where else besides Glasgow is there a FullScale Structures Testing Unit, which does not need much money because there are so many derelict buildings in Scotland just waiting to be blown up? In this context could be found discussions on everything from topics of the day, such as cancer, acquired immune deficiency syndrome (AIDS) and acid rain, to the censoring of isolated naked quarks.

Studying quarks, be they naked, down or up, sparked an ongoing debate on the proper role of public opinion in science funding. "Not with my money" is a public response dangerous to basic scientists, whose work often has no obvious immediate value for Britain's well-being. As Professor G.G. Roberts, head of applied physics at Durham, said, research in such fields as quarks "should be restricted" un- til the United Kingdom "can afford the luxury of financing them".

At the science audit, Sir David Phillips, chairman of the Advisory Council for the Research Councils (ABRC), outlined the history of another kind of planning blight He pointed to a scientific malaise in industrial countries, caused by the necessary reduction in their percentages of world scientific activity as the Third World develops. The science vote in Britain increased in real terms by a factor of 50 since 1930 , but has now levelled off. Only "outmoded attitudes" lead scientists to expect a return to expansion.

There was no paucity of fingers pointing at causes for the decline in British research. Professor C. Hilsum, chief scientist, GEC Research Laboratories, for example, claimed that Britain's financial institutions make competing with the Japanese more difficult. British companies, he says, have an average of onethird the fixed assets of Japanese companies, partly because they expect a much higher return on those assets than do the Japanese. The high ownership of shares in UK businesses by pension funds and investment trusts ( 58 per cent as opposed to 20 per cent in Japan) encourages "liquidity without commitment, more finance and less business".

Industry is an obvious target. According to Sir Hans Kornberg, industry should recognize the importance of basic research in universities to its own growth and thus provide more support at an early stage. The research divisions of companies are also an important link between basic and applied science. Mr R.A. Street from the Palo Alto Research Center in California described these divisions as an avenue for attracting top people to the company and as a door to the universities. Dr I.A. Shanks from Unilever outlined how, when these doors close, ideas from outside can be strangulated by industrial fear of unprotected ideas and new market areas.

The research councils and their methods of funding are a problem very close to home for the scientists they support. These councils were set up after the First World War, according to Sir David, as a means of improving the economic performance of Britain. Since then they have been described as too compartmentalized properly to compare competing sources for funds as well as too outdated to analyse multidisciplinary research such as biosensors. SERC, for instance, is divided into nuclear physics, astronomy and space science and, belatedly, engineering. With the slashing of budgets, nuclear physics has been a dramatic loser.

The audit had an aura of stewing in its own juice. There are too few carrots available for prodding the development of a much evidence of what happens without one. The feeling of getting nowhere, of finding no solution, led one nuclear physicist in the audience to proclaim, "We may be the first to go but we won't be the last".

How, then, should excellence be identified? One method, now much in vogue, that adds statistical backing to peer reviews and interviews is citation analysis. These data can show both trends in fields and excellence of individual researchers. For example, an analysis of the most cited papers across all fields by the Institute for Scientific Information in Philadelphia shows "a distinct absence of physics and chemistry" papers from the United Kingdom but strength in biomedical and biological areas. ABRC has funded several citation analyses from Ben Martin and John Irvine of the Science Policy Research Unit (SPRU) of the University of Sussex.

Given the shrinking UK funding pie, however, excellence cannot be properly supported in all fields. Who and by what means those choices can be made are questions that promise to draw blood. "No one institution could cope", says Sir David, but at the same time "bottom-up" procedures suffer from narrow specialization. He set forth another option: discussion among all the fields involved, including all interested parties, which would result in a "consensus that needs no other implementation". Dr Hillsum also pointed to the Japanese forecasts that create national goals and thus national achievement.

Interest in this avenue for national policy making has been stimulated by Martin and Irvine's book Foresight in Science, which resulted from a study funded by ABRC on Japanese policy formation. It describes how the Japanese Science and Technology Committee gathers responses from active researchers, over half in industry, on what is likely to be achieved in thcse fields. National goals result, which, because of the previous participation, are more easily accepted. This option was not taken seriously in the BA audit discussions, but it is likely that ABRC will try out a method similar to that described by Martin and Irvine.

The large number of people at the physics sessions on the beginning and future of the Universe were a telling comment on criticism of basic research, even if the precise role of the down quark is not essential for UK industrial growth. Maybe, on the other hand, they were there because the axioms were different. In the new big bang theory as described by the quantum physicist Professor P.C.W. Davies, activities do not have to have well-defined causes, the big bang is an "inflation" (used in a positive sense) of a whimper into empty space and energy is created from nothing. An even pleasanter thought was Dr Davies' support of a statement from Dr Alan Guth of MIT: "the Universe is a free lunch".

Elizabeth Collins 